\title{
KAJIAN HAK ATAS KEKAYAAN INTEKTUAL KEKUATAN MENGIKAT KLAUSULA RAHASIA DAGANG SETELAH BERAKHIRNYA PERJANJIAN KERJA
}

\author{
Elis Qomatul Lailyyah, Mahasiswa Fakultas Hukum Universitas 17 Agustus 1945 \\ Surabaya, E-mail: qomatul@gmail.com.
}

Irit Suseno, Dosen Fakultas Hukum Universitas 17 Agustus 1945 Surabaya' E-mail: suseno@gmailcom

\begin{abstract}
ABSTRAKSI
Perdagangan bebas yang memperluas ruang gerak arus transaksi barang dan/atau jasa yang didalamnya terdapat sumber daya yang sangat berharga yang berupa HAKI seperti rahasia dagang yang harus dilindungi. Permasalahan dari penelitian ini adalah Bagaimana mengikatnya klausula Rahasia Dagang setelah berakhirnya perjanjian kerja dan Upaya hukum apa yang dapat dilakukan oleh pemilik Rahasia Dagang sebagai akibat berakhirnya perjanjian kerja. Jenis Penelitian yang digunakan adalah Penelitian Hukum Normatif (normative legal research). Hasil penelitian pertama ini menyimpulkan bahwa mengikatnya klausula rahasia dagang setelah berakhirnya perjanjian kerja adalah tergantung pada perjanjian dan kesepakatan antara para pihak tentang jangka waktu berlakunya klausula tersebut. Dan upaya hukum yang dapat dilakukan pemilik rahasia dagang adalah berdasarkan dengan peraturan perundangan Rahasia Dagang.

Kata Kunci: Rahasia Dagang, Klausula, Perjanjian Kerja
\end{abstract}

\section{PENDAHULUAN}

\section{Latar Belakang}

Globalisasi dan perdagangan bebas yang didukung oleh kemajuan tekhnologi komunikasi dan informatika telah memperluas ruang gerak arus transaksi barang dan/atau jasa yang ditawarkan oleh pelaku usaha bervariasi baik produk luar negeri maupun produk dalam negeri. Tingginya frekuensi keluar masuk dan berpindah-pindahnya sumber daya manusia dari satu perusahaan ke parusahaan lainnya, bahkan antar perusahaan yang berbeda negara telah menjadi ciri dalam era globalisasi perdagangan yang tidak dapat dihindari. Terkait dengan globaliasi dan perdagangan Ahmad M.Ramli menyatakan bahwa:

Terdapat keterkaitan yang sangat erat antara perlindungan atas Rahasia Dagang (trade secrets) atau yang dikenal juga dengan informasi yang dirahasiakan yang merupakan bagian dari Hak atas kekayaan intelektual yang selanjutnya disebut HAKI dengan globalisasi perdagangan, karena dewasa ini masalah perdagangan internasional tidak hanya akan berkaitan dengan barang dan jasa semata, tetapi di dalamnya juga terlibat sumber daya lain berupa HAKI seperti Rahasia Dagang, paten, merek, hak cipta, desain industri serta hak-hak lain yang terkait dalam lingkup HAKI. ${ }^{1}$

1 Ahmad M.Ramli, H.A.K.I Hak Atas Kepemilikan Intelektual: Teori Dasar Perlindungan Rahasia Dagang Bandung: Mandar Maju, 2000, hlm. 1 
Rahasia Dagang sebagai salah satu bagian dari HAKI, merupakan hak yang cukup tinggi dalam perkembangan aktivitas bisnis di Indonesia. Hal ini ditandai dengan keseriusan pemerintah dalam menangani permasalahan tersebut sehingga diundangkannya UU No. 30 Tahun 2000 tentang Rahasia Dagang yang mulai berlaku sejak 20 September 2000 dengan dilatarbelakangi oleh ratifikasi perjanjian WTO/TRIP's melalui UU No. 7 Tahun 1994 serta diundangkannya UU No. 5 Tahun 1999 tentang Larangan Praktek Monopoli dan Persaingan Tidak Sehat yang menunjukkan bahwa pokok pikiran dari UU Rahasia Dagang di Indonesia telah sejalan dengan pemikiran TRIP's sebagai bagian dari perjanjian dalam WTO. ${ }^{2}$

Berkenaan dengan itu maka : "investor dan pelaku bisnis merasa sangat berkepentingan terhadap adanya Perlindungan Rahasia Dagang miliknya melalui sistem perlindungan Hak Kekayaan intelektual (HAKI)"3. Dipandang dari sudut pandang hukum hal ini sangat beralasan, sebab pelanggaran terhadap rahasia dagang akan sangat merugikan penemuatau pemilik hak tersebut. Rahasia Dagang merupakan faktor yang sangat penting dalam upaya persaingan dagang yang jujur (fair competation), sekaligus merupakan komoditas yang sangat berharga dan memiliki nilai ekonomis yang tinggi. ${ }^{4}$

Maka dari itu demi memajukan industri yang mampu bersaing dalam lingkup perdagangan nasional dan internasional perlu diciptakan iklim yang mendorong kreasi dan inovasi masyarakat dengan memberikan perlindungan hukum terhadap Rahasia Dagang saat berlangsungnya perjanjian kerja, maupun saat berakhirnya perjanjian kerja sebagai bagian dari sistem Hak Kekayaan Intelektual, selain untuk memajukan dunia industri perdagangan barang dan/atau jasa perlu dilakukan pembangunan nasional. Pembangunan nasional dilaksanakan dalam rangka pembangunan manusia Indonesia seutuhnya dan pembangunan masyarakat Indonesia seluruhnya untuk mewujudkan masyarakat yang sejahtera, adil, makmur, yang merata, baik materiil maupun spiritual berdasarkan Pancasila dan Undang Undang Dasar Negara Republik Indonesia Tahun 1945.

Perlindungan Rahasia Dagang juga semakin penting jika dikaitkan dengan hubungan antar perusahaan dan karyawannya. Keberadaan Penanaman Modal Asing yang tidak melibatkan unsur luar perusahaan saat ini sudah dimungkinkan di Indonesia dengan kebijakan pemerintah yang menyatakan dibolehkannya bentuk Penanaman Modal Asing 100\% saham dalam suatu PT

2 Gunawan Widjaja. Rahasia Dagang, Seri Hukum Bisnis, Jakarta: PT. Raja Grafindo Persada, 2001, hlm. 100.

${ }^{3}$ Ahmad M.Ramli, Loc.Cit.hlm.1

${ }^{4}$ Ibid, hlm.2 
sangat penting artinya, terutama apabila bidang usaha PT tersebut melibatkan HAKI termasuk Paten dan Rahasia Dagang. ${ }^{5}$

Undang-Undang No.30 Tahun 2000 Tentang Rahasia Dagang yang selanjutnya disebut sebagai Undang-Undang Rahasia Dagang Pasal 1 ayat (1) menyatakan bahwa Rahasia Dagang adalah informasi yang tidak diketahui oleh umum di bidang teknologi dan/atau bisnis, mempunyai nilai ekonomi karena berguna dalam kegiatan usaha, dan dijaga kerahasiaannya oleh pemilik Rahasia Dagang.Hal ini berarti bahwa Undang-Undang Rahasia Dagang tidak membatasi informasi di bidang teknologi semata tetapi didalamnya juga mencakup informasi non-tekhnologi.

Berdasarkan Pasal 4 Undang-Undang No. 30 Tahun 2000 Tentang Rahasia Dagang bahwa pemilik rahasia dagang mempunyai hak monopoli untuk menggunakan sendiri rahasia dagang yang dimilikinya dalam kegiatan bisnis untuk memperoleh keuntungan ekonomis, ketentuan ini juga berarti bahwa hanya pemilik rahasia dagag yang berhak untuk memberikan ijin kepada pihak lain untuk menggunakan rahasia dagang yang dimilikinya melalui perjanjian lisensi. Selain itu pemilik rahasia dagang juga berhak melarang pihak lain untuk menggunakan atau mengungkapkan rahsia dagang yang dimilikinya kepada pihak ketiga apabla pengungkapan tersebut dilakukan untuk kepentingan yang bersifat komersial. ${ }^{6}$

Rahasia dagang harus tetap terjaga kerahasiaanya oleh pemiliknya termasuk oleh pekerjanya, agar tidak terjadi permasalahan antara pemilik dan pekerja maka diperlukan sebuah perjanjian kerja atau peraturan perusahaan yang didalamnya memuatkesepakatan antara pemberi kerja dengan pekerja yang nantinyadapat melindungi kerahasiaan suatu rahasia dagang perusahaan.

Undang-Undang No. 13 Tahun 2003 tentang Ketenagakerjaan yang selanjutnya disebut sebagai Undang-Undang KetenagakerjaanPasal 1 angka 14 menyatakan bahwa :

\section{Pasal 1 angka 14}

Perjanjian kerja adalah perjanjian antara pekerja/buruh dengan pengusaha atau pemberi kerja yang memuat syarat syarat kerja, hak, dan kewajiban para pihak.

Terkait dengan pengertian perjanjian kerja berdasarkan UndaangUndang diatas, pendapat lain menurut Wiwoho Soedjono mengatakan bahwa :" perjanjian kerja adalah suatu perjanjian dimana pihak yang satu dengan pihak lainnya sebagai majikan dengan mendapatkan upah selama waktu tertentu."7

Pasal 52 ayat (1) Undang-Undang No.13 Tahun 2003 Tentang Ketenagakerjaan menyatakan bahwa:

$$
\text { Pasal } 52 \text { ayat (1) }
$$

\footnotetext{
${ }^{5}$ Komar Kantaatmadja, Undang-Undang Perseroan Terbatas 1995 dan Implikasinya TerhadapPenanaman Modal Asing, Bandung, 1995, hlm.1

${ }^{6}$ Ahmad M.Ramli, Op.Cit, hlm. 5

7 Wiwoho Soedjono, Hukum Perjanjian Kerja (Yogyakarta: Rineka Cipta) hlm.10
} 
Perjanjian kerja dibuat atas dasar :

a. kesepakatan kedua belah pihak;

b. kemampuan atau kecakapan melakukan perbuatan hukum; c. adanya pekerjaan yang diperjanjikan; dan

c. pekerjaan yang diperjanjikan tidak bertentangan dengan ketertiban umum, kesusilaan, dan peraturan perundang undangan yang berlaku.

Fx. Djumialdji dalam bukunya menyatakan bahwa : "Dengan terjadinya perjanjian kerja akan menimbulkan hubungan kerja antara buruh dengan majikan/pengusaha yang berisi hak-hak dan kewajiban-kewajiban bagi masingmasing pihak". 8

Berdasarkan berbagai peraturan perundangan di bidang perburuhan, tidak ada ketentuan yang melarang adanya perjanjian untuk menjaga kerahasiaan suatu informasi yang dimiliki perusahaan. Dari hal tersebut dapat dipahami bahwa adanya kesepakatan antara pengusaha dan buruhnya yang menimbulkan kewajiban bagi buruhnya untuk menjaga kerahasiaan informasi perusahaan tempat ia bekerja tidak bertentangan dengan peraturan perundangan yang berlaku dandapat dilakukan oleh pengusaha dalam rangka melindungi informasi yg rahasia dalam perusahaanya.

Seperti yang pada umumnya terjadi saat ini banyak terdapat perusahaanperusahaan yang tidak membuat perjanjian kerjayang didalamnya terdapat klausula larangan untuk mengungkapkan Rahasia Dagang perusahaan mereka. Mereka tidak membuat perjanjian kerja/peraturan perusahaan tersebut karena menurut mereka dengan sistem kepercayaan sudah cukup, padahal sebenarnya itu justru tidak melindungi rahasia dagang yang mereka miliki. Faktanya kasus Rahasia Dagang setelah usainya perjanjian kerja dapat dilihat dari kasus terkenal berikut ini yang diputus di negeri Belanda, yaitu kasus Cohen versus Lindenbaum. Secara singkatnya kasus Cohen versus Lindenbaum sebagai berikut:

Cohen dan Lindenbaum merupakan dua buah perusahaan percetakan yang saling bersaing antara satu sama lainnya. Kasus ini berawal dari penerimaan buruh Lindenbaum oleh Cohen melalui suatu tindakan yang dinilai tidak etis dalam dunia usaha. Buruh Lindenbaum tersebut dijanjikan banyak hadiah apabila mau pindah ke Cohen dengan syarat memberikan segala macam informasi maupun data miliknya yang berhubungan dengan jalannya kegiatan oprasional Lindenbaum. Selain itu diberikan pula informasi mengenai pembelian, pemasok, penjualan, promosi, pelanggan, serta proses penentuan harga. Dari Informasi yang diperolehnya, Cohen kemudian menyusun strateginya untuk merebut dan menguasai pangsa pasar Lindenbaum. Lindenbaum yang mengetahui hal tersebut mengajukan gugatan dengan dasar

${ }^{8}$ Fx. Djumialdji, Perjanjian Kerja, Jakarta : Bumi Aksara, hlm.39 
perbuatan melawan hukum. Di pengadilan tingkat pertama dan kedua, gugatan tersebut tidak berhasil, namun oleh Mahkamah Agung gugatan diterima. ${ }^{9}$

Berdasarkan uraian kasus diatas maka persoalan Rahasia Dagang yang seharusnya tetap terjaga meskipun seseorang pekerja telah keluar atau putus hubungan kerjanya dengan perusahaan pemilik Rahasia Dagang. Nampaknya perlu perjanjian-perjanjian atau aturan-aturan yang jelas mengenai hubungan hukum antara keryawan yang sudah keluar dari perusahaan tempat bekerjanya karyawan tersebut selaku pemilik Rahasia Dagang.

\section{Rumusan Masalah}

1. Bagaimana mengikatnya klausula Rahasia Dagang setelah berakhirnya perjanjian kerja?

2. Upaya hukum apa yang dapat dilakukan oleh pemilik Rahasia Dagang sebagai akibat berakhirnya perjanjian kerja?

\section{METODE PENELITIAN}

Jenis penelitian yang digunakan dalam penelitian ini adalah Penelitian Hukum Normatif (normative legal research). Hal-hal yang dikaji dalam penelitian hukum normatif meliputi beberapa hal seperti asas-asas hukum, sistematika hukum, taraf sinkronisasi hukum, perbandingan hukum dan sejarah hukum. Penelitian hukum sendiri merupakan suatu proses untuk menemukan jawaban atas problematika hukum yang terjadi di bidang hukum kekayaan intelektual khususnya di bidang Rahasia Dagang, maupun doktrin-doktrin hukum guna menjawab isu hukum yang dihadapainya.Metode berpikir yang digunakan adalah metode berpikir deduktif dimana penelitian menggunakan cara berpikir yang sifatnya umum ke khusus.

Dalam kaitannya dengan penelitian hukum normatif, akan digunakan 2 pendekatan yaitu :

a) Pendekatan Perundang-undangan (statute approach)

"Metode pendekatan perundang-undangaan (statute approach) dilakukan dengan menelaah semua undang-undang dan regulasi yang bersangkutan dengat isu hukum yang sedang terjadi dan peneliti juga perlu memahami hierarki dan asasasas dalam perundang-undangan."10 Dalam penelitian ini penulis menggunakan metode pendekatan Undang-Undang No. 30 Tahun 2000 Tentang Rahasia Dagang dengan Undang-Undang No. 13 Tahun 2003 Tentang Ketenagakerjaan.

b) Pendekatan Konsep

"Metode pendekatan konsep merupakan metode pendekatan yang dilakukan karena memang belum atau tidak adanya aturan hukum untuk masalah yang sedang dihadapi. Dalam menggunakan pendekatan konsep ini peneliti merujuk

${ }_{9}^{9}$ Adrian Sutedi, Hak Atas Kekayaan Intelektual. Jakarta: Sinar Grafika, 2009, hlm.129

10 Peter Mahmud. M, Penelitian Hukum,Jakarta: Prenadamedia Group, 2005, hlm.133 
pada prinsip-prinsip hukum yang dapat ditemukan dari pandangan-pandangan saejana ataupun doktrin-doktrin hukum."11

Sumber dan Jenis Bahan Hukum yang digunakan dalam penelitian ini adalah Bahan Hukum Primer dan Bahan Hukum Sekunder. Bahan hukum primer adalah bahan hukum yang bersifat autoritatif, artinya mempunyai otoritas. Bahan hukum primer ini terdiri dari perundang-undangan, catatancatatan resmi atau risalah dalam pembuatan perundang-undangan dan putusanputusan hakim.Dalam penelitian ini menggunkan bahan hukum primer sebagai berikut:

1) Undang-Undang Dasar Republik Indonesia Tahun 1945

2) Kitab Undang-Undang Hukum Perdata

3) Kitab Undang-Undang Hukum Pidana (KUHP).

4) Undang-Undang Nomor 5 tahun 1999 tentang Larangan Praktik Monopoli dan Persaingan Usaha Tidak Sehat.

5) Undang-Undang No.30 Tahun 2000 Tentang Rahasia Dagang.

6) Undang-Undang No. 13 Tahun 2003 Tentang Ketenagakerjaan.

Bahan Hukum Sekundermerupakan bahan hukum yang berupa semua publikasi tentang hukum yang bukan merupakan dokumen-dokumen resmi. Dalam bahan hukum sekunder yang terutama adalah buku-buku hukum termasuk skripsi, tesis, dan disertasi hukum dan jurnal-jurnal hukum, disamping itu juga komentar putusan pengadilan. ${ }^{12}$ Dalam penelitian ini menggunakan bahan hukum sekunder berupaliteratur-literatur maupun jurnal dan karya ilmiah lainya terkait dengan permasalahan yang diteliti dalam penulisan ini. Pengumpulan Bahan Hukum dalam penelitian ini dilakukan melalui studi kepustakaan (library research), yaitu studi yang dilakukan dengan cara mempelajari buku-buku, peraturan perundang-undangan serta dokumendokumen lainnya yang terkait dengan penulisan ini khususnya tentang Rahasia Dagang dan Perjanjian kerja. Dalam hal ini yang dimaksud dengan studi kepustakaan dalam penelitian ini adalah mempelajari dan menganalisasecara sistematis bahan-bahan hukum tersebut diatas yang terkait dengan Rahasia Dagang dan perjanjian kerja.Metode analisa bahan hukum ditempuh dengan cara mengkaji materi yang sudah ada serta dianalisa secara interpretatif meggunakan teori maupun hukum positif yang telah diterapkan, kemudian disusun secara sistematis, degan menggunakan logika berfikir deduktif yaitu dianalisis dari hal yang bersifat umum kepada permasalahan yang lebih khusus sehingga dapat ditarik kesimpulan untuk menjawab permasalahan yang ada dalam penelitian ini.

11Ibid, hlm.177-178

${ }^{12}$ Ibid, hlm. 195-196 


\section{PEMBAHASAN}

\section{Rahasia Dagang}

Rahasia Dagang (trade secret) atau yang kini dikenal dengan informasi yang dirahasiakan merupakan bagian dari HAKI yang sejajar dengan bentukbentuk HAKI lainnya seperti paten, merek, desain produk industri, hak cipta, dan lain-lain.Istilah Rahasia dagang dikenal secara luas dalam hukum angloSaxon dan dipergunakan baik dalam produk-produk hukum maupun kepustakaan hukum. ${ }^{13}$

Rahasia Dagang saat ini bahkan dipilih sebagai bentuk perlindungan di samping bentuk perlindungan HAKI lainnya seperti paten dan hak cipta, karena Rahasia Dagang justru dapat melindungi informasi-informasi penting yang semula tidak dapat diindungi di bawah hukum paten, hak cipta, desain produk industri dan merek. Dasar filosofis perlindungan informasi yang dirahasiakan adalah karena informasi yang dimiliki diperolehnya melalui pemikiranpemikiran dan memerlukan keahlian khusus, menghabiskan banyak waktu dan biaya. Oleh sebab itu sangatlah perlu suatu perlindungan hukum terhadap Rahasia Dagang itu sendiri. Untuk lebih memahami, maka berikut ini akan dijelaskan mengenai pengertian Rahasia Dagang.

Istilah rahasia dagang berbeda-beda di beberapa negara. Sementara dalam Uniform Trade Secret Act (Canada) menyatakan bahwa rahasia dagang merupakan setiap informasi yang dapat digunakan dalam suatu perdagangan yang tidak merupakan informasi umum dan memiliki nilai ekonomis. Dari ketentuan Uniform Trade Secret Act (Canada) dapat dilihat bahwa undang-undang tersebut tidak hanya membatasi bentuk rahasia dagang pada suatu rumus, pola rencana, kompilasi, program komputer, teknik, proses, produk, perangkat atau mekanisme semata-mata. ${ }^{14}$

Sedangkan di Indonesia pengertian Rahasia Dagang dapat kita lihat dalam Undang-Undang No.30 Tahun 2000 Tentang Rahasia Dagang mengatur pengertian atau definisi Rahasia Dagang dalam rumusan Pasal 1 angka 1 sebagai berikut:

\section{Pasal 1}

"Rahasia Dagang adalah informasi yang tidak diketahui oleh umum di bidang teknologi dan/atau bisnis, mempunyai nilai ekonomi karena berguna dalam kegitan usaha dan dijaga kerahasiaannya oleh pemilik rahasia dagang."

Berdasarkan pengertian diatas maka dapat kita simpulkan bahwa Rahasia Dagang adalah sebuah informasi yang sangat berharga untuk perusahaan, karenanya harus dijaga kerahasiannya. Keberhargaan informasi ini

${ }^{13}$ Ahmad M. Ramli, Op. Cit, hlm. 31-32

${ }^{14} \mathrm{Ibid}$, hlm. 6 
karena informasi tersebut dapat mendatangkan keuntungan ekonomis bagi perusahaan. ${ }^{15}$

Undang-Undang Rahasia Dagang tidak hanya membatasi informasi dalam hal teknologi saja melainkan dalam hal non-teknologi. Dalam Undang-Undang rahasia dagang tepatnya dalam Pasal 2 juga dijelaskan bahwa yang menjadi obyek perlindungan rahasia dagang adalah informasi yang meliputi metode produksi, metode pengolahan, metode penjualan, atau informasi lain di bidang teknologi dan/atau bisnis yang memiliki nilai ekonomis dan tidak diketahui oleh masyarakat.

Dari pengertian tersebut diatas, dikatakan oleh Gunawan Widjaja bahwa:

"pemilik Rahasia Dagang adalah penemu atau orginator dari informasiinformasi yang dirahasiakan tersebut, yang disebut dengan Rahasia Dagang. Sedangkan pemegang Rahasia Dagang adalah pemilik Rahasia Dagang dan pihak-pihak yang memperoleh hak lebih lanjut dari Pemilik Rahasia Dagang, yang terjadi sebagai akibat berlakunya ketentuan Pasal 5 ayat (1) UndangUndang Rahasia Dagang."16

Sebelum kita membahas tentang kategori suatu Rahasia Dagang, terlebih dahulu kita bahas mengenai subyek Rahasia Dagang. Dari penjelasan diatas dapat di lihat bahwa Rahasia Dagang merupakan sebuah kekayaan intelektual yg dimiliki oleh manusia, dalam hal ini yang merupakan subyek Rahasia Dagang adalah pemilik Rahasia Dagang dan Pemegang Rahasia dagang itu sendiri, pemilik Rahasia Dagang berhak untuk memegag Rahasia Dagang itu sendiri secara pribadi dan dapat juga memberikan Hak kepada orang lain untuk memlikinya melalui peralihan hak dan lisensi. Undang-Undang Rahasia Dagang membedakan antara pemilik Rahasia Dagang dan Pemegang Rahasia Dagang, seperti yang tersirat dalam Pasal 5 ayat (1) Undang-Undang Rahasia Dagang yang mengakui dimungkinkannya atau terjadinya peralihan Hak Rahasia Dagang, yang dapat dilakukan atau terjadi melalui :

Pasal 5 ayat (1)

1) Pewarisan;

2) Hibah;

3) Wasiat;

4) Perjanjian tertulis; atau

5) Sebab-sebab lain yang dibenarkan peraturan perundang-undangan.

Sebagaimana didefinisikan, Rahasia Dagang merupakan suatu bentuk informasi rahasia yang wajib dijaga kerahasiaanya oleh pemilik Rahasia Dagang atau pemegang Rahasia Dagang itu sendiri. Sesuatu untuk dapat dikategorikan sebagai rahasia dagang yaitu apabila informasi itu memiliki nilai komersil jika

${ }^{15}$ Adrian Sutedi, Op. Cit, hlm. 122

16 Gunawan Widjaja, Seri Hukum Bisnis: Rahasia Dagang, Jakarta:PT. Raja Grafindo Persada, 2001, hlm. 85 
digunakan dalam suatu kegiatan usaha atau pun jasa demi meningkatkan keuntungan secara ekonomi, informasi dianggap dijaga kerahasiaanya apabila pemegang/pemilik rahasia dagang telah melakukan perlindungan rahasia dagang itu sendiri dengan cara menjaga dan mempertahankan kerahasiaan itu.

Undang-undang No. 30 Tahun 2000 tentang Rahasia Dagang memberikan lingkup perlindungan Rahasia Dagang adalah :

a. Metode Produksi;

b. Metode Pengolahan;

c. Metode Penjualan, dan;

d. Informasi lain di bidang tekhnologi, dan/atau di bidang bisnis yang memiliki nilai ekonomi, serta tidak diketahui oleh masyarakat.

Adapun yang dimaksudkan dalam informasi tekhnologi adalah :17

a. Informasi tentang penelitian dan pengembangan suatu tekhnologi;

b. Informasi tentang produksi/proses;

c. Informasi mengenai kontrol menu.

Sedangkan yang dimakasudkan dalam informasi bisnis adalah :

a. Informasi yang berkaitan dengan penjualan dan pemasaran suatu produk;

b. Informasi yang berkaitan dengan para langganan;

c. Informasi tntang keuangan;

d. Informasi tentang administrasi.

Jadi perlu diketahui, bahwa informasi yang terdapat pada iklan, brosur dan buku panduan pengoprasian, informasi bahan pada kemasan makanan seperti komposisi adalah informasi yang tidak lagi dikatgorikan dalam informasi rahasia (confindental information). Karena informasi-informasi tersebut sudah termasuk ke dalam informasi-informasi umum, dimana masyarakat luas telah mengetahui dan wajib untuk megetahui informasi tersebut. Seperti yang telah diatur dalam Undang-Undang No. 8 Tahun 1999 Tentang Perlindungan Konsumen, bahwa setiap produk makanan yang akan diperjual belikan wajib disertakan informasi bahan dan nilai gizi suatu makanan tersebut. Disini dapat kita lihat bahwa informasi yang telah menjadi konsumsi publik, tidaklah termasuk dalam kategori informasi rahasia.

Dalam Uniform Trade Secrets Act (1979) yang merupakan salah satu sumber hukum Rahasia Dagang di Amerika Serikat, menentukan bahwa substansi atau ruang lingkup Rahasia Dagang yang dilindungi adalah suatau rumus, pola, kompilasi, program, alat, metode, teknik, atau proses yang menghasilkan nilai ekonomi secara mandiri, nyata atau potensial.

Untuk mengetahui apakah suatu informasi tersebut merupakan informasi rahasia (confindental information), maka informasi tersebut terlebih dahulu diuji melalui ukuran sebagai berikut :18

${ }_{17}$ Adrian Sutedi, Loc. Cit, hlm. 122 


\section{a. Tingkat Kerahasiaan}

Pertama-tama informasi itu harus diukur sampai taraf mana informasi itu diketahui oleh kalangan luar. Disini, pemilik informasi rahasi tersebut harus dapat membuktikan bahwa informasi tersebut benar-benar hanya diketahui olehnya dan bukan merupakan informasi yang bersifat umum serta sejauh mana dan dengan cara bagaimana informasi itu diketahui oleh pihak lain yang terkait dengan kegiatan bisnisnya.

b. Keterlibatan dengan karyawan

Sampai sejauh mana informasi itu diketahui oleh karyawan di dalam perusahaan tersebut dan bagaimana pengaruhnya terhadap usaha perusahaan serta sampai sejauh mana informasi tersebut akan menguntungkan pihak lain jika sampai bocor kepada pihak ketiga. Ukuran pihak ketiga dimungkinkan memperoleh keuntungan jika rahasi itu jatuh ke tangannya merupakan syarat bahwa informasi itu dapat dikualifikasikan sebagai informasi rahasia.

c. Tingkat menjaga kerahasiaan

Sampai sejauh mana pemilik informasi berupaya menjaga kerahasiaan informasinya itu. Upaya menjaga kerahasiaan informasi ini merupakan suatu yang bersifat wajib, karena tindakan-tindaka yang bersifat lalai dapat menyebabkan pemilik Rahasia Dagang kehilangan haknya.

d. Nilai informasi untuk kompetitor

Sampai sejauh mana informasi tersebut berpengaruh terhadap kompetitor jika samai bocor, apakah informasi itu akan memberikan kemungkinan kompetitor untuk memperoleh keuntungan lebih atau dapat menyebabkan pemilik akan kehilangan keutungan yang semestinya.

e. Tingkat perlindungan dan nilai komersial informasi

Seseorang yang menyatakan sebagai pemilik Rahasia Dagang juga harus dapat membuktikan bahwa informasi itu merupakan hasil dari pemikirannya dan menunjukkan upaya untuk menjaga kerahasiaanya.

f. Tingkat kesulitan dalam memperoleh informasi

Sampai sejauh mana tingkat kesulitan untuk memperoleh dan memiliki informasi itu dan sampai sejauh mana kesulitannya jika berdasarkan informasi tersebut orang lain menggandakan hasil dari informasi tersebut. Harusnya, informasi tersebut sangatlah sukar untuk disadap atau digandaka karena kesungguhan pemiliknya untuk menjaga kerahasiaan informasi itu.

\section{Mengikatnya klausula Rahasia Dagang setelah berakhirnya perjanjian kerja}

Informasi rahasia suatu perusahaan adalah semua informasi yang berkaitan dengan perusahaan tersebut yang sangat berharga dan tidak boleh diketahui oleh perusahaan lain terutama terhadap perusahaan yang bersaing. Kerahasiaan suatu informasi dapat dan harus dijamin kerahasiaanya, selama informasi belum

${ }_{18}$ Ahmad Ramli, Op.Cit, hlm.37-42 
dibuka ke publik atau dipublikasikan dan masih dipertahankan oleh pemiliknya. Perusahaan dalam hal ini adalah perusahaan yang bergerak dalam usaha dagang yang bersifat komersial, yang dapat mendatangkan nilai ekonomi dan mendapatkan keuntungansehingga informasi yang bersifat rahasia dari perusahaan dapat disebut sebagai rahasia dagang.

Kekayaan Intelektual dan kemampuan khusus seorang ahli yang didapat dalam perusahaan dapat dianggap sebagai informasi yang berharga atau rahasia bila hal tersebut diakui oleh perusahaan yang bersangkutan. Menjaga Rahasia Dagang pada suatu perusahaan tidaklah menjadi semua tanggung jawab pekerja/buruh pada perusahaan tersebut, namun pengusaha hanya menunjuk salah satu pekerja/buruh yang dipercaya menyimpan dan atau melaksanakan tanggung jawab atas rahasia dagang tersebut pada saat ditandatanganinya sebuah perjanjian pemberi kuasa dengan demikian tanggung jawab atas rahasia dagang selalu melekat pada pengusaha dan pekerja.Sehingga dengan berpindahnya sumber daya manusia dari satu perusahaan ke perusahaan lainnya tidak berarti bahwa orang tersebut dapat menggunakan rahasia dagang yang dimiliki perusahaan yang ditinggalkannya untuk dimanfaatkan pada perusahaan barunya. Oleh karena itu pembuatan kontrak kerja yang melindungi rahasia dagang baik itu bersifat formula, proses produksi, daftar pelanggan, metode-metode dan sebagainya menjadi sangat penting untuk dilakukan oleh pemilik Rahasia dagang.

Rahasia dagang merupakan harta kekayaan pribadi seseorang yang bersifat privat. Kepemilikan hak atas kekayaan intelektual memberikan kekuasaan langsung kepada pemilik untuk mengalihkan atau memberikan haknya kepada kepada pihak lain. Sebagaimana diatur dalam Pasal 1570 KUHPerdata yang menjelaskan bahwa hak milik adalah hak yang paling sempurna atas suatu benda seorang yang mempunyai hak milik atas suatu benda dapat berbuat apa saja dengan benda itu (menjual, menggadaikan, memberikan) asalkan tidak melanggar peraturan perundang-undangan yang berlaku.

Rahasia dagang sebagai hak milik tentunya dapat beralih kepemilikannya kepada pihak lain. Dalam Pasal 5 Undang-undang Rahasia dagang menyatakan bahwa hak rahasia dagang dapat beralih atau dialihkan dengan:

a) Pewarisan

b) Hibah

c) Wasiat

d) Perjanjian tertulis atau

e) Sebab-sebab lain yang dibenarkan oleh peraturan perundang-undangan.

Khusus untuk pengalihan hak atas dasar perjanjian, diperlukan adanya suatu pengalihan hak yang didasarkan pada pembuatan akta otentik. Contoh pengalihan hak dengan perjanjian tertulis adalah perjanjian lisensi, yakni peilik rahasia dagang memberikan lisensi kepada pihak lain berdasarkan perjanjian 
lisensi tersebut untuk melaksanakan atau menggunakan hak rahasia dagang dalam kegiatan yang bersifat komersial. Berbeda dengan perjanjian yang menjadi dasar pengalihan rahasia dagang yang lain, lisensi hanya memberikan hak secara terbatas dan dengan waktu yang terbatas pula. Dengan demikian, lisensi diberikan dalam jangka waktu tertentu.

Berkaitan dengan itu, Ahmad M. Ramli menyatakan bahwa:

Selama memberikan lisensi, pemilik rahasia dagang tetap boleh melaksanakan sendiri atau memberi lisensi kepada pihak ketiga berkaitan dengan rahasia dagang yg dimilikinya. Dengan demikian pada prinsipnya perjanjian lisensi bersifat non-esklusif, artinya tetap memberika kemungkinan kepada pemilik rahasia dagang untuk memberikan lisensi kepada pihak ketiga. ${ }^{19}$

Seorang pemilik rahasia dagang diwajibkan memelihara dan menjaga kerahasiaan yang dimilikinya. Sebagaimana dicantumkan dalam Pasal 1 Undang-Undang Rahasia Dagang dijaga kerahasiaannya oleh pemilik rahasia dagang. Hal itu dapat dilakukan melalui berbagai langkah seperti melalui pembuatan kontrak yang isinya secara eksplisit mewajibkan pihak lain untuk tidak membocorkan rahasia itu secara tertulis. Kontrak tertulis semacam ini akan sangat membantu khususnya untuk menghindarkan kesalahpahaman atas ruang lingkup yang harus dirahasiakan. ${ }^{20}$

Hal yang perlu diperhatikan dalam membuat perjanjian atau kontrak kerja dengan pekerja dasarnya adalah Pasal 1320, dalam Pasal 1320 ayat (1) Kitab Undang-Undang Hukum Perdata disebutkan beberapa syarat sahnya suatu perjanjian, yakni:

1. Sepakat

2. Cakap untuk membuat suatu perjanjian.

3. Mengenai suatu hal tertentu

4. Suatu sebab yang halal.

Asas kebebasan berkontrak dalam hal ini dapat tetap berlaku sejauh tidak bertentangan dengan kaidah atau peraturan dalam hukum perburuhan. Sutan Remy Sjahdeini menyatakan beberapa ruang lingkup asas kebebasan berkontrak sebagai berikut:21

1. Kebebasan untuk membuat atau tidak membuat perjanjian;

2. Kebebasan untuk memilih dengan pihak siapa ia ingin membuat perjanjian;

3. Kebebasan untuk memilih causa perjanjian yang akan dibuatnya;

4. Kebebasan untuk menentukan objek suatu perjanjian;

5. Kebebasan untuk menentukan bentuk suatu perjanjian;

${ }^{19}$ Ahmad M. Ramli, Op. Cit, hlm. 7-8

${ }^{20} \mathrm{Ibid}, \mathrm{hlm} .82$

${ }^{21}$ Sutan Remy Sjahdeini, Kebebasan Berkontrak dan Perlindungan Yang Seimbang bagi Para Pihak dalam Perjanjian Kredit di Indonesia. (Jakarta : Institut Bankir Indonesia, 1993, hlm.47 
6. Kebebasan untuk menerima atau menyimpangi ketentuan undang-undang yang bersifat opsional (aanvullen, optional).

Kebebasan Berkontrak adalah salah satu asas yang sangat penting di dalam Hukum Perjanjian. Kebebasan ini adalah perwujudan dari kehendak bebas, pancaran hak asasi manusia. Kebebasan berkontrak ini berlatar belakang pada paham individualisme yang secara embrional lahir dalam zaman Yunani. Menurut faham individulisme, setiap orang bebas untuk memperoleh apa yang dikehendakinya. Di dalam Hukum Perjanjian, falsafah ini diwujudkan dalam "kebebasan berkontrak". 22

Merujuk pada pemikiran dialektis Hegel yang menegaskan bahwa kebebasan membuat kontrak merupakan konsekuensi dari pengakuan akan adanya hak milik sedangkan hak milik itu sendiri merupakan realisasi yang utama dari kebebasan individu. Hak milik merupakan landasan bagi hak-hak lain. Menurut Hegel kebebasan berkehendak merupakan landasan yang substansial bagi semua hak dan kewajiban, sehingga mewarnai perundangundangan dan moral. Pemegang hak milik harus menghormati orang lain yang juga pemegang hak milik, adanya saling menghormati hak milik inilah yang merupakan landasan terjadinya hukum kontrak. Dari penjelasan Hegel di atas dapat dipahami bahwa esensi asas kebebasan membuat kontrak adalah saling mempertahankan eksistensi masing-masing pihak. ${ }^{23}$

Dalam sebuah kontrak perjanjian, apabila salah satu pihak tidak telah lalai degan tidak meakukan prestasinya maka dapat dikatakan sebagai wanprestasi, Wanprestasi adalah tidak terlaksananya prestasi atau kewajiban sebagaimana mestinya yang dibebankan oleh kontrak terhadap para pihaknya.Tindakan wanprestasi membawa konsekuensi terhadap timbulnya hak pihak yangdirugikan untuk menuntut pihak yang melakukan wanprestasi untuk memberikanganti kerugian akibat perbuatannya. Suatu hal dapat dikatakan wanprestasi jika terpenuhinya salah satu hal berikut:

1) Tidak melaksanakan atau memenuhi prestasi ;

2) Terlambat memenuhi prestasi ;

3) Tidak sempurna memenuhi prestasi.

Kewajiban dalam memelihara kerahasian ini juga dapat di tempuh melalui ketentuan-ketentuan yang bersifat implisit. Pada prinsipnya hukum akan melindungi kerahasian itu berdasarkan asas-asas hukum perjanjian itu tidak hanya mencakup apa yang telah secara eksplisit diperjanjikan, tetapi mencakup juga kebiasaan-kebiasaan meskipun tidak secara tegas dinyatakan seperti tercantum dalam pasal 1347 BW yang menyatakan: "Hal-hal yang menurut

22Mariam Darus Badrulzaman, dkk.,Kompilasi Hukum Perikatan, Bandung:Citra Aditya Bakti, 2001, hlm.83

${ }^{23}$ Muhammad Syaifuddin, hlm. 83 
kebiasaan selamanya diperjanjikan, dianggap secara diam-diam dimasukan dalam persetujuan, meskipun tidak dengan tegas dinyatakan." 24

Contoh klausula untuk melindungi rahasia dagang adalah sebagai berikut :

1. Bersikap setia dan jujur terhadap perusahaan.

Memegang teguh rahasia dagang perusahaan dan tidak akan membocorkan kepada pihak ketiga atau lain: Pembuatan atau proses pembuatan segala macam produk dari perusahaan tersebut pengetahuan yang dimiliki perusahaan dalam hal teknologi, prosedur, metode atau sistem dan operasionalperusahaan. Surat-surat baik yang sifatnya resmi maupun tidak, soal pembukuan, perencanaanatau planning,penentuanAnggaran dan semua surat-surat atau data-data lain yang bersangkutan dengan dokumen tersebut satu dan lain dalam arti kata seluas-luasnya.

2. Selama masa 2 (dua) tahun setelah berakhirnya hubungan kerja penandatangan dengan perusahaan, penandatangan tidak akan bekerja pada atau bertindak sebagai agen untuk atau konsultan bagi siapapun atau perusahaan apapun yang mengusahakan pengembangan, pembuatan atau penjualan produk apapun yang bersaing langsung dengan produk apapun yang dijual oleh perusahaan di dalam wilayah apapun dimana produk termaksud dibuat atau dijual. Klausula ini dapat melindungi rahasia dagang yang dimilki pengusaha, baik dalam masa berlakunya perjanjian dan setelah berakhirnya perjanjian. Dan terakhir yang keempat sebab yang halal, apapun isi dari perjanjian asal tidak bertentangan dengan undang-undang. ${ }^{25}$

Sedangkan dalam hubungan kerja antara pengusaha dan pekerja/buruh, Seorang pemilik rahasia dagang wajib memelihara dan menjaga kerahasiaan atas informasi yang dimilikinya. Hal itu dapat dilakukan melalui berbagai langkah seperti melalui pembuatan kontrak yang isinya secara eksplisit mewajibkan pihak lain untuk tidak membocorkan rahasia itu secara tertulis. Kontrak tertulis semacam ini akan sangat membantu khususnya untuk menghindarkan kesalahpahaman atas ruang lingkup yang harus dirahasiakan.Dalam praktik, pencantuman klausula-klausula tentang rahasia dagang atau pembuatan perjanjian-perjanjian khusus tentang rahasia dagang merupakan hal yang sangat penting. Hal ini dikarenakan rahasia dagang merupakan aset perusahaan yang sangat mahal, karena rahasia dagang itulah yang akan menjadi alat yang sangat ampuh untuk melakukan kompetisi dengan para kompetitor dalam kalangan pengusaha dan perdagangan. Disamping itu para pelaku bisnis juga sangat menyadari bahwa langkah-langkah melindungi rahasia dagang melalui sistem hukumkontrak adalah salah satu strategi yuridis untuk melindungi rahasia

${ }^{24}$ R. Subekti \& R Tjitrosudibio, Kitab Undang-undang Hukum Perdata, Jakarta : Pradnya Paramita, 1980, hlm. 308.

${ }^{25}$ Agustina Ni Made Ayu Darma, Perlindungan Hukum Rahasia Dagang Setelah Berakhirnya Perjanjian Kerja, Universitas Atma Jaya Yogyakarta, 2014, hlm. 22 
dagang itu sendiri, yang nantinya dapat dijadikan bukti bahwa pemiliknya secara sungguh-sungguh telah melakukan perlindungan optimal terhadap rahasia dagang yang dimilikinya.

Dalam rangka menjamin kepastian hukum juga perlu dibuatnya perjanjian tentang perlindungan rahasia dagang ini. Kemudian, jika terjadi sengketa dengan pekerja/buruh atau dengan pihak ketiga, maka klausula dalam perjanjian ini akan menjadi bukti yang kuat bahwa perusahaanlah pemiliki informasi yang bersifat rahasia itu, dan juga bahwa rahasia itu hanya dapat dipergunakan untuk kegiatan bisnis perusahaan itu saja. Jika dianalisis lebih lanjut dari segi perlindungan rahasia dagang dalam kaitan hubungan antara pekerja/buruh dengan pengusaha terkait dengan ketentuan-ketentuan KUHPerdata lainnya yang menyangkut kewajiban-kewajiban seorang pekerja/buruh terhadap pemberi kerja (pengusaha) yang mempekerjakannya seperti yang telah diatur dalam Pasal 1603b KUHPerdata yang menyatakan:

\section{Pasal 1603b}

"Buruh diwajibkan menaati aturan-aturan tentang hal melakukannya pekerjaan serta aturan-aturan yang ditujukan pada perbaikan tata tertib dalam perusahaan si majikan, yang diberikan kepadanya oleh atau atas nama majikan di dalam batas-batas aturan-aturan undang-undang atau persetujuan maupun regleman, atau jika itu tidak ada menurut kebiasaan."

Dalam perlindungan rahasia dagang pada umumnyadibuat secara tertulis yang berisikan tentang ketentuan atau perjanjian tentang kewajiban pihak pekerja/buruh untuk tidak membocorkan rahasia dagang kepada pihak yang tidak berwenang, namun pasal ini telah memberikan perlindungan bahwa tanpa perjanjian atau aturan perusahaan semacam itu pun pekerja/buruh seharusnya tidak melakukan pembocoran rahasia dagang karena berdasarkan kebiasaan dan secara etika.

Suatu perjanjian kerahasiaan informasi rahasia dagang setidaknya memuat hal-hal berikut:

1. Apa saja yang menjadi informasi rahasia dan alasan kerahasiaan.

2. Kepada siapa informasi tersebut diberikan dan alasan diberikan.

3. Apa yang boleh dilakukan dan apa yang tidak boleh dilakukan terhadap informasi tersebut.

4. Kapan informasi dianggap disalahgunakan atau dilanggar;

5. Kapan informasi tersebut dianggap tidak lagi menjadi rahasia (dilepaskan). ${ }^{26}$

Kewajiban untuk menjaga rahasia dagang suatuperusahaan ternyata tidak hanyadibebankan pada pekerja saja. Tetapi pengusaha juga diwajibkan memelihara danmenjaga rahasia dagang yang dimiliki sebagaimana dicantumkan dalam Pasal 1 UURD, dan Pasal 3 ayat (4) UURD menentukan

26http:// wacanahukum.blogspot.co.id/2013/02/perlindungan-hukum-rahasiadagang_20.htmlyang diakses pada tgl 21 Januari 2018 Pukul 17:31 
bahwa : "Informasi dianggap dijaga kerahasiannya apabila pemilik atau para pihak yang menguasainya telah melakukan langkah langkah yanglayak dan patut."

Adapun yang dimaksud dengan langkah yang layak dan patut adalah langah-langkah baik eksternal maupun internal perusahaan yang dilakukan agar informasi yang dianggap rahasia tersebut tidak dapat dengan mudah diakses, atau diketahui oleh orang yang tidak berhak, baik pekerja/buruh maupun bukan pekerja/buruh. ${ }^{27}$ Misalnya dalam suatu perusahaan ada prosedur baku cara penyimpanan arsip-arsip yang dirahasiakan. Ataupun membuat kontrak dengan karyawan yang isinya secara eksplisit mewajibkan pihak lain untuk tidak membocorkan rahasia itu secara tertulis. Kontrak tertulis semacam ini akan sangat membantu khususnya untuk menghindarkan kesalahpahaman atas ruang lingkup yang harus dirahasiakan. ${ }^{28}$

Di samping itu dalam KUHPidana juga mewajibkan pekerja/buruh untuk menjaga rahasia perusahaan sebagaimana dinyatakan dalam Pasal 322 ayat (1) KUHPidana yaitu :

Pasal 322 ayat (1)

“Barang siapa dengan sengaja membuka rahasia yang wajib disimpannya karena jabatan atau pencahariannya, baik yang sekarang maupun yang dahulu, diancam dengan pidana penjara paling lama 9 (Sembilan) bulan atau denda dan seterusnya."

Selanjutnya dalam Pasal 323 ayat (1) KUHPidana juga menyatakan:

Pasal 323 ayat (1)

“Barang siapa dengan sengaja memberitahukan hal-hal khusus tentang suatu perusahaan dagang, kerajinan, atau pertanian, di mana ia kerja atau dahulu bekerja, yang olehnya harus dirahasiakan diancam pidana penjara paling lama 9 (Sembilan) bulan dan seterusnya."

Jadi, sesungguhnya dalam ketentuan KUHPidanamemberikan perlindungan terhadap perbuatan pembocoran rahasia dagang (undisclosed information). Pokokpokok penting yang dilindungi, antara lain adalah sebagai berikut:

1. Bahwa seseorang dilarang membuka rahasia yang wajib disimpannya berdasarkan jabatan atau mata pencahariannya. Artinya, dasar kewajibannya tidak membocorkan kedudukan atau jabatannya. Jadi, dalam suatu hubungan kontrak karya misalnya. Yang punya kewajiban tidak membocorkan rahasia ialah si pegawai.

2. Bahwa rahasia ini tidak terbatas pada rahasia pada saat dia bekerja, tetapi juga rahasia-rahasia ini harusnya ia pegang setelah ia tidak bekerja. Segala informasikhusus yang menyangkut perusahaan dagang kerajinan atau

27 Gunawan Widjaja, Op. Cit, hlm. 83

28 Ahmad M. Ramli, Op. Cit, hlm. 82 
pertanian, juga memberikan perlindungan terhadap pembocoran pada rahasia dagang, yang demikian di kualifikasikan sebagai tindak pidana.

\subsection{Perjanjian Kerja Kerahasiaan dan Perjanjian Kerja Persaiangan}

Pada umumnya suatu hubungan hukum terjadi karena adanya suatu perjanjian yang mendahului hubungan hukum tersebut. Begitu juga hubungan hukum yang timbul antara perusahaan dengan pegawainya, terjadi karena adanya suatu perjanjian kerja yang mendahului hubungan hukum di anatar mereka. Di era sekarang perjanjian kerja bukanlah satu-satunya perjanjian yang mengatur hubungan antara majikan dengan buruh saja, seiring dengan perkembangan dunia usaha dan tingginya mobilitas pegawai, semakin banyak ragam perjanjian yang dibuat untuk mengatur hubungan antara majikan dan pekerja/buruh ataupun pelaku usaha dengan pegawainya. Sebagai contoh employee confidentiality agreement yang mengatur kewajiban pegawai untuk menjaga kerahasiaan suatu rahasia dagang.

Employee confidentiality agreement merupakan perjanjian antara pihak perusahaan dengan pekerja/buruh dimana perusahaan sebagai pemilik informasi yang dirahasiakan mencantumkan klausula mengenai kewajiban pekerja/buruh untuk menjaga kerahasiaan informasi bisnis perusahaan terhadap pihak lain dan berharap informasi tersebut tetap terjaga kerahasiannya. ${ }^{29}$ Pada intinya perjanjian ini dimaksudkan agar pekerja/buruh sadar akan kewajibannya selama bekerja untuk menjaga kerahasiaanya serta bagaimana menjalankan rahasia dagang itu ketika bekerja diperusahaan tersebut. Dalam perjanjian ini tertulis secara jelas apa saja yg termauk rahasia dagang yang harus dijaga kerahasiaanya oleh pekerja/buruh yang diberikan kepercayaan untuk menjaganya.

Sedangkan yang dimaksud dengan perjanjian kerja persaiangan, yang dikenal dengan istilah Convenant to the Compete adalah sebuah perjanjian yang mewajibkan mantan pekerja/buruh untuk tidak bekerja di bidang pekerjaan yang sama dengan bidang usaha di perusahaan sebelumnya, yaitu perusaahaan tempat ia bekerja sebelumnya dalam satu area untuk waktu tertentu setelah berhenti bekerja. ${ }^{30}$ Perjanjian ini bisa berupa perjanjian yang terpisah dengan perjanjian kerja atau disatukan dalam bentuk klausula dalam suatu perjanjian kerja terkait. Dapat penulis simpulkan bahwa perjanjian Employee confidentiality agreement berlaku selama pekerja/buruh ada hubungan kerja dengan perusahaan terkait sedangkan Convenant to the Compete (Perjanjian kerja persaigan) berlaku setelah berakhirnya pejanjian kerja.

${ }^{29}$ Mark J. Hanson, Joe R. Thompson, dan Joel J. Dahlgren, Overview of confidentiallity agreement, www.extension.iastate.edu/agdm/wholefarm/html/c5-80.html, 5 Januari 2018 pukul 20:00 WIB.

30 Roger E. Schechter, Unifair Trade practices and intellectual property, 2 Ed, St Paul: West publishing co. 1993. P. 162 
Beberapa kewajiban pekerja/buruh masih berlangsung bahkan setelah pekerjaan itu berakhir. Jika ada klausula pembatasan yang dapat dilaksanakan dalam prjanjian kerjanya, misalnya seorang pekerja boleh dibatasi pekerjaanya yang akan datang dalam batas waktu dan jarak yang ditentuakan. Begitupun juga kewajiban merahasiakan sesuatu, seperti rahasia dagang juga boleh berlangsung bahkan dalam hal tidak adanya klausula tertentu dalam perjanjian, walaupun memang seharusnya merupakan kebijakan bagi majikan untuk membuat klasusula tersebut pada perjanjian kerja. Bekas pekerja bleh dibatasi dari penggunaan informasi rahasia yang diperoleh selama melakukan pekerjaannya, tetapi bukan pengetahuan umum atau keahlian yang ia peroleh kemudian.

Tidak adanya peraturan perundangan yang mengatur secara eksplisit mengenai perjanjian antara pekerja dengan pengusaha terhadap adanya kewajiban untuk menjaga rahasia dagang setelah perjanjian itu berakhir di tempatnya bekerja baik dalam UU nomor 30 Tahun 2000 tentang Rahasia Dagang, peraturan perundangan di bidang perburuhan, UU Nomor 5 Tahun 1999 tentang Larangan Praktik Monopoli dan Persaingan Usaha Tidak Sehat, Kitab Undang-undang Hukum Perdata, dan Kitab Undang-undang Hukum Pidana, bukan berarti tidak ada pengaturan terhadap hal tersebut. Dalam praktiknya, perjanjian mengenai rahasia dagang ini diatur dalam perjanjian kerja antara pekerja dengan pengusaha. ${ }^{31}$

Dalam berbagai peraturan perundang-undangan di bidang perburuhan, tidak ada ketentuan yang melarang adanya perjanjian untuk menjaga kerahasiaan suatu informasi yang dimiliki oleh suatu perusahaan. Akhirnya dapat ditarik kesimpulan, bahwa adanya kesepakatan antara pengusaha dan pekerjanya yang menimbulkan kewajiban bagi buruhnya untuk menjaga kerahasiaan informasi perusahaan tempat ia bekerja (rahasia dagang perusahaannya), tidak bertentangan dengan peraturan perundangan yang berlaku dan dapat dilakukan oleh pengusaha dalam rangka melindungi informasinya yang berharga. ${ }^{32}$

3. Upaya hukum pemilik Rahasia Dagang sebagai akibat dari berakhirnya perjanjian kerja

Dari adanya berbagai bentuk "perjanjian" yang mengakibatkan terjadinya persaingan curang, terdapat juga berbagai "kegiatan" yang juga dapat mengakibatkan terjadinya suatu persaingan curang, sehingga hal tersebut harus dilarang. Salah satu bentuk tindakan monopoli yang dapat mengakibatkan praktik monopoli dan persaingan usaha tidak sehat adalah penguasaan atas poduksi dan/atau pemasaran barang dan/atau jasa. Pengaturan larangannya

${ }^{31}$ Adrian Sutedi, Op. Cit , hlm. 131

${ }^{32} \mathrm{Ibid}, \mathrm{hlm} .132$ 
terdapat dalam ketentuan Pasal 17 Undang-Undang No. 5 Tahun 1999 tentang Larangan praktek Monopoli dan Persaingan Usaha Tidak Sehat, yang menentukan sebagai berikut:

\section{Pasal 17}

(1) "Pelaku Usaha dilarang melakukan penguasaan atas produksi dan atau pemasaran barang dan atau jasa yang dapat mengakibatkan terjadinya praktek monopoli dan atau persaingan usaha tidak sehat.

(2) Pelaku usaha patut diduga atau dianggap melakukan penguasaan atas produksi dan atau pemasaran barang dan atau jasa sebagaimana dimaksud dalam ayat (1) apabila:

a. Barang dan atau jasa yang bersangkutan belum ada substansinya; atau

b. Mengakibatkan pelaku usaha lain tidak dapat masuk ke dalam persaingan usaha barang dan atau jasa yang sama; dan

c. Satu pelaku usaha atau satu kelompok pelaku usaha menguasai lebih dari 50 \% (lima puluh persen) pangsa pasar satu jenis barang atau jasa tertentu."

Dalam konteks yuridis tidak semua bentuk kegiatan monopoli dilarang, hanya kegiatan monopoli yang mengakibatkan terjadinya praktik monopoli dan/atau persaingan usaha tidak sehat yang dapat dilarang. Seperti halnya pengungkapan rahasia dagang suatu perusahaan kepada perusahaan yang bidangnya sama.Adanya pasar monopoli dapat menimbulkan pemutusan ekonomi pada pelaku usaha, yang dimana akan terjadi persaingan usaha yang sehat tidak sehat dan keadaan ini tentunya akan sangat merugikan.

Semetara itu dalam Undang-Undang No. 5 Tahun 1999, merumuskan pengertian persaingan usaha tidak sehat sebagaimana dalam Pasal 1 angka 6 .

\section{Pasal 1 angka 6}

"Persaingan usaha tidak sehat adalah persaingan antar pelaku usaha dalam menjalankan kegiatan produksi dan atau pemasaran barang dan atau jasa yang dilakukan dengan cara tidak jujur atau melawan hukum atau menghambat persaingan usaha."

Istilah lain persaingan usaha tidak sehat adalah persaingan curang (unfair competition) atau praktik bisnis yang tidak jujur. Jadi persaingan usaha tidak sehat itu adalah suatu persaingan usaha yang dilakukan oleh antar pelaku usaha secara tidak jujur atau melawan hukum atau menghambat persaingan usaha. Pelaku usaha disini melakukan cara-cara persaingan usaha yang tidak jujur, melawan hukum, atau setidak-tidaknya perbuatan yang dilakukan pelaku usaha tersebut dapat menghambat persaingan usaha.

Praktik bisnis yang tidak jujur dapat diartikan sebagai segala tingkah laku yang tidak sesuai dengan itikad baik, kejujuran didalam berusaha. Perbuatan ini termasuk perbuatan melawan hukum. Karenanya praktik bisnis yang tidak jujur dilarang, dapat mematikan persaingan yang sebenarnya ataupun merugikan 
perusahaan pesaing secara tidak wajar/tidak sehat dan juga dapat merugikan konsumen. ${ }^{33}$

Terkait persaingan usaha tidak sehat, rahasia dagang suatu perusahaan merupakan komponen yang sangat penting dalam hal persaingan usaha antar pelaku usaha, apalagi suatu perusahaan yang mempunyai bidang yang sama.Rahasia dagang merupakan harta kekayaan pribadi seseorang yang sangat berharga sehingga sudah sepatutnya untuk diupayakan penjagaanya agar tidak terjadi monopoli/persaingan usaha tidak sehat dalam pasar.

Berkaitan dengan upaya mempertahankan rahasia dagang, dalam hal ini pemilik rahasia dagang berhak atas kepemilikannya. Berdasarkan pasal 4 UU Rahasia Dagang ini, pemilik rahasia dagang mempunyai hak monopoli untuk menggunakan sendiri rahasia dagang yang dimilikinya dalam kegiatan bisnis untuk memperoleh keuntungan ekonomis. Ketentuan ini juga berarti bahwa hanya pemilik rahasia dagang yang berhak untukmemberikan izin kepada pihak lain untuk menggunakan rahasia dagang yang dimilikinya melalui perjanjian lisensi. Selain itu, pemilik rahasia dagang juga berhak melarang pihak lain untuk menggunakan atau mengungkapkan rahasia dagang yang dimilikinya kepada pihak ketiga apabila pengungkapan tersebut dilakukan untuk kepentingan yang bersifat komersial.

Pasal 4 UU Rahasia menentukan hak-hak yang dimiliki pemilik rahasia dagang itu, yaitu berhak untuk:

1. Menggunakan sendiri rahasia dagang yang dimilikinya.

2. Memberikan lisensi kepada atau melarang pihak lain untuk menggunakan rahasia dagang atau mengungkapkan rahasia dagang itu kepada pihak ketiga untukkepentingan yang bersifat komersial.

Upaya menjaga kerahasiaan ini merupakan suatu hal yang sangat penting, karena tindakan-tindakan yang bersifat lalai dapat menyebabkan pemilik rahasia dagang kehilangan haknya. Jika rahasia dagang ini terpublikasi maka perlindungan atas kepemilikan rahasia dagang terebut akan terancam. Bentuk pemeliharaan rahasia dagang dapat lahir karena adaya hubungan antara pihak yang memberi Informasi dan yang menerimanya berdasarkan asas keseimbangan, dengan kata lain para pihak harus melakukan kewajiban secara adil sebagai bukti adanya saling percaya satu sama lain, hal ini biasanya dituangkan dalam suatu kontrak yang klausulanya adalah tidak akan membocorkan rahasia satu sama lain.

Guna memberikan perlindungan rahasia dagang, tidak ada yang membatasi tentang jangka waktu berlakunya perlindungan rahasia dagang yaitu selama pemiliknya tetap merahasiakan dan meakukan usaha-usaha untuk melindungi

33 Janus Sidabalok, Hukum Perlindungan Konsumen di Indonesia: Dengan Pembahasan atas Undang-Undang No. 8 Tahun 1999. Bandung: Citra Adity Bakti, 2006, hlm. 222-223 
kerahasiaannya maka selama itu pula berlaku perlindungan hukum. Misalnya formula coca-cola tetap dijaga kerahasiannya, yaitu dengan cara membatasi 2 orang saja yang mengetahui formula tersebut. ${ }^{34}$

Upaya hukum yang dapat dilakukan oleh Pemilik rahasia dagang untuk tetap melindungi rahasia dagang tersebut adalah dengan cara melakukan perjanjian terlebih dahulu. Dimana perjanjian tersebut didalamnya terdapat klausula yang mengatur tentang menjaga kerahasiaan informasi dalam suatu perusahaan tersebut. Kemudian didalam perjanjian tersebut dicantumkan klausula yang mengatur mengenai kewajiban kepada pekerja/buruh untuk tidak mengungkapkan rahasia dagang setelah berakhirnya perjanjian kerja dengan waktu yang telah ditentukan bersama. Upaya sebagaimana mestinya yang dimaksud adalah semua langkah yang memuat ukuran kewajaran, kelayakan dan kepatutan yang harus dilakukan misalnya dalam suatu perusahaan harus ada prosedur baku berdasarkan praktik umum yang dalam ketentuan internal perusahaan itu sendiri demikian pula dalam ketentuan internal perusahaan dapat ditetapkan bagaimana rahasia dagang itu dijaga dan siapa yang bertangungjawab atas kerahasiaan itu.

Terdapat upaya lain yang dapat dilakukan oleh pemilik rahasia dagang untuk dapat melindungi rahasia dagangnya khususnya saat berakhirnya perjanjian kerja, yaitu dengan membatasi pemberian informasi rahasia dagang tersebut terhadap pekerja/buruh, Misalnya pemberian informasi hanya jika memang diperlukan saja, dan informasi tersebut yang mengenai metode produksi dan lainnya hanya diberitahukan kepada salah satu pekerja saja yang dapat dipercaya akan menjaga rahasia dagang tersebut.

Sedangkan dalam Undang-Undang Rahasia Dagang memberikan penjelasan pemilik rahasia dagang telah menjaga rahasia dagangnya apabila telah melakukan langkah-langkah yang layak dan patut namun Undang-Undang tersebut tidak menjelaskan lebih lanjut tentang hal tersebut. Dalam praktek langkah-langkah tertentu dapat dilakukan untuk menjaga kerahasiaan diantaranya:

1. Mengungkapkan rahasia dagang hanya kepada orang-orang yang perlu mengetahuinya atas dasar sebuah perjanjian rahasia dagang;

2. Membuat perjanjian rahasia dagang dengan pegawai atau pihak ketiga;

3. Melindungi data yang bersifat rahasia dengan membuat kode rahasia;

4. Menyimpan dokumen-dokumen rahasia ditempat yang aman dan tidak bisa diakses dengan mudah oleh karyawan atau pihak lain;

5. Mencantumkan kata "rahasia" pada bagian luar dokumen rahasia;

6. Membatasi akses para pegawai untuk memasuki unit atau departemen lain dari sebuah perusahaan;

${ }^{34}$ Adrian Sutedi, Op. Cit, hlm.126 
7. Melarang pegawai bekerja di luar jam kerja yang telah ditentukan. ${ }^{35}$

8. Dalam perjanjian kerja antara perusahaan dengan karyawan harus diatur secara tegas ketentuan tentang larangan pengungkapan rahasia dagang di luar tugastugasnya seperti jika berhubungan dengan pihak lain yang tidak terikat dalamperjanjian.

Namun, apabila pemilik rahasia dagang telah lalai tidak membuat peraturan mengenai kewajiban pemegang informasi rahasia tersebut untuk menjaga kerahasiaannya, maka pemilik rahasia dagang tidak perlu khawatir. Hal tersebut karena pada dasarnya setiap pihak yang telah diberikan informasi rahasia tersebut memiliki kewajiban secara langsung ataupun tidak langsung untuk menjaga kerahasiaan informasi tersebut dan dilarang untuk mengungkapkan atau menyebarkan informasi tersebut tanpa seizin dari pemilik rahasia dagang tersebut, terutama terhadap informasi yang telah diberikan perlindungan rahasia dagang, maka secara otomatis Undang-Undang Rahasia Dagang akan melindungi kerahasiaan informasi terebut. Karena pada dasarnya perlindungan Rahasia Dagang beda dengan perlindungan HAKI yang lainnya seperti merek, paten, dll.

\subsection{Penyelesaiaan Sengketa Pelanggaran Klausula Rahasia Dagang setelah berakhirnya perjanjian kerja.}

Pada dasarnya, penyelesaian sengketa di dalam suatu perjanjian atau kontrak ditempuh dengan cara yang telah disepakatai oleh para pihak yang membuat perjanjian tersebut. Hal ini juga berlaku didalam perjanjian merahasiakan rahasia dagang suatu perusahaan saat dan atau sesudah perjanjian kerja. Ketika membuat perjanjian kerja tersebut, pekerja/buruh dengan pengusaha telah menyepakati cara penyelesaian sengketa apabila nanti dikemudian hari terjadi sebuah permasalahan, termasuk didalamnya apabila nantinya ada suatu pelanggaran terhadap salah satu kalusula dalam perjanjian yang telah dibuat. Perselisihan ini bisa saja penyelesaian segketanya melalui jalan damai, misalnya saja hanya dengan ganti rugi saja, atau dengan cara menyampaikan gugatan ke pengadilan yang berwenang, para pihak harus melaksanakan dengan seksama.

Dalam UNIDROIT, dinyatakan bahwa pelanggaran terhadap kerahasiaan menimbulkan tanggung jawab untuk mengganti kerugian. Jumlah kerugian yang harus dibayar dapat bermacam-macam, tergantung pada apakah para pihak telah membuat persetujuan khusus atau tidak mengenai ganti kerugian. Bahkan apabila pihak pemilik rahasia dagang yang dilanggar tidak menderita kerugian apapun, ia berhak ata keuntungan yang didapat karena mengungkapkan informasi tersebut kepada pihak ketiga atau menggunakannya untuk

35Iman Sjahputra Tunggal dan Heri Herjandono, Rahasia Dagang (Trade Secret) Seluk Beluk Tanya Jawab, Teori dan Praktek, Jakarta: Harvarindo, 2000, hlm. 28-29 
kepentingan sendiri. Aabila perlu, misalnya ketka informasi belum dibuka sepenuhnya atau telah dibuka sebagian, pihak yang dirugikan dapat meminta keputusan dari hakim berdasarkan peraturan perundang-undangan yang berlaku.

Sedangkan menurut hukum positif di Indonesia, apabila terjadi pelanggaran terhadap pencantuman klausula kerahasiaan rahasia dagang mengacu terhadap Undang-Undang No. 30 Tahun 2000 tentang Rahasia Dagang. Dalam undangundang tersebut menyatakan bahwa, terdapat dua penyelesaian sengketa terhadap pelanggaran klausula rahasia dagang tersebut, yaitu melalui gugatan pengadilan atau dapat juga dengan gugatan/tuntutan Pidana.

Berkenaan dengan upaya yang dilakukan pemilik rahasia dagang haruslah dapat melindungi dan menjaga kerahasiaan suatu rahasia dagang itu sendiri, dan menjadi suatu hak dan kewajiban untuk pemilik rahasia dagang untuk menggunakan, dan mengalihkan rahasia dagangnya sendiri. Jika terjadi suatu sengketa atas pelanggaran klausula kerahasia rahasia dagang itu sendiri maka pemilik rahasia dagang dapat melakukan beberapa hal seperti yang sudah diatur dalam Undang-undang Rahasia Dagang, diantaranya adalah yang diejalsakan dalam Pasal 11 dan Pasal 12 Undang-Undang Rahasia Dagang sebagai berikut :

\section{Pasal 11}

(1) Pemegang Hak Rahasia Dagang atau penerima Lisensi dapat menggugat siapa pun yang dengan sengaja dan tanpa hak melakukan perbuatan sebagaimana dimaksud dalam Pasal 4, berupa: a. gugatan ganti rugi; dan/atau b. penghentian semua perbuatan sebagaimana dalam Pasal 4.

(2) Gugatan sebagiamana dimaksud dalam ayat (1) diajukan ke Pengadilan Negeri.

Pasal 12

Selain penyelesaian gugatan sebagaimana dimaksud dalam Pasal 11, para pihak dapat menyelesaikan perselisihan tersebut melalui arbitrase atau alternatif penyelesaian sengketa.

\section{KESIMPULAN}

Bahwa Pengakhiran perjanjian atau kontrak terjadi karena habisnya jangka waktu perjanjian, maka tanggal pengakhiran kontrak atau perjanjian ditetapkan adalah hari terakhir perjanjian ini masih berlaku, kemudian setelah berakhirnya kontrak atau perjanjian tersebut maka para pihak sudah tidak terikat lagi dan tidak mempunyai kewajiban apapun.Secara yuridis perlindungan rahasia dagang akan tetap terlindungi meskipun perjanjian kerja telah berakhir karena Undang-Undang secara langsung melindungi rahasia dagang tersebut.Upaya hukum yang harus ditempuh oleh pemilik rahasia dagang sebagai akibat berakhirnya perjanjian kerja apabila terjadi perselisihan atau sengketa mengenai rahasia dagang suatu perusahaan atau jika pada perjanjian/kontrak yang dibuat oleh para pihak adalah dengan cara melakukan perjanjian terlebih dahulu. 
Dimana perjanjian tersebut didalamnya terdapat klausula yang mengatur tentang menjaga kerahasiaan informasi dalam suatu perusahaan tersebut. Kemudian didalam perjanjian tersebut dicantumkan klausula yang mengatur mengenai kewajiban kepada pekerja/buruh untuk tidak mengungkapkan rahasia dagang setelah berakhirnya perjanjian kerja dengan waktu yang telah ditentukan bersama. Dalam hal jika terjadi sengketa, sudah diatur dalam Undang-Undang Rahasia Dagang mengacu terhadap Undang-Undang No. 30 Tahun 2000 tentang Rahasia Dagang. Dalam undang-undang tersebut menyatakan bahwa, terdapat dua penyelesaian sengketa terhadap pelanggaran klausula rahasia dagang tersebut, yaitu melalui gugatan pengadilan atau dapat juga dengan gugatan Pidana. Yang sebelumnya dapat dilakukan damai terlebih dahulu antara kedua belah pihak, jika tidak mencapai penyelesaiaan maka dapat diajukan gugatan kepada pengadilan yang berwenang.

Perlu adanya aturan yang jelas mengenai mengikatnya klausula rahasia dagang setelah berakhirnya perjanjian kerja baik itu dari Undang-Undang Rahasia Dagang, Undang-Undang Ketenagakerjaan, maupun Undang-Undang Larangan Monopoli dan Persaingan Usaha Tidak Sehat, karena belum ada aturan yang mengatur secara eksplisit.Untuk mencegah terjadinya pelanggaran rahasia dagang sebaiknya perjanjian itu dibuat secara tertulis sesuai dengan peraturan perundang-undangan yang mengatur, sehingga mempunyai kekuasaan hukum tetap. 


\section{DAFTAR BACAAN}

Buku:

Adrian, Sutedi, Hak Atas Kekayaan Intelektual. Jakarta: Sinar Grafika, 2009.

Ahmad, M.Ramli, H.A.K.I Hak Atas Kepemilikan Intelektual: Teori Dasar Perlindungan Rahasia Dagang, Bandung: Mandar Maju, 2000.

Darus, Badrulzaman Mariam, dkk., Kompilasi Hukum Perikatan, Bandung:Citra Aditya Bakti, 2001.

Djumialdji Fx. ,Perjanjian Kerja, Jakarta : Bumi Aksara.

Gunawan, Widjaja, Rahasia Dagang, Seri Hukum Bisnis, Jakarta: PT. Raja Grafindo Persada, 2001.

Iman, Tunggal Sjahputra dan Herjandono, Heri, Rahasia Dagang (Trade Secret) Seluk Beluk Tanya Jawab, Teori dan Praktek, Jakarta: Harvarindo, 2000.

Janus, Sidabalok, Hukum Perlindungan Konsumen di Indonesia: Dengan Pembahasan atas Undang-Undang No. 8 Tahun 1999. Bandung: Citra Adity Bakti, 2006.

Komar, Kantaatmadja, Undang-Undang Perseroan Terbatas 1995 dan Implikasinya TerhadapPenanaman Modal Asing, Bandung, 1995.

Peter. M, Mahmud, Penelitian Hukum, Jakarta: Prenadamedia Group, 2005.

Remy, Sjahdeini Sutan, Kebebasan Berkontrak dan Perlindungan Yang Seimbang bagi Para Pihak dalam Perjanjian Kredit di Indonesia. Jakarta : InstitutBankir Indonesia, 1993.

Roger, Schechter. E, Unifair Trade practices and intellectual property, 2 Ed, St Paul: West publishing co., 1993.

Tjitrosudibio R \& Subekti R., Kitab Undang-undang Hukum Perdata, Jakarta : Pradnya Paramita, 1980.

Wiwoho, Soedjono, Hukum Perjanjian Kerja, Yogyakarta: Rineka Cipta.

Internet:

http:// wacanahukum.blogspot.co.id/2013/02/perlindungan-hukum-rahasia dagang_20.html yang diakses pada tgl 21 Januari 2018 Pukul 17:31

Mark J. Hanson, Joe R. Thompson, dan Joel J. Dahlgren, Overview of confidentiallity agreement, www.extension.iastate.edu/agdm/wholefarm/html/c5-80.html, 5 Januari 2018 pukul 20:00 WIB. 